\title{
Changes in the lipid profile of neutered cats' blood in cases of obesity and diabetes
}

\author{
Inna V. Chala ${ }^{1}$, Diana V. Feshchenko, Oksana A. Dubova ${ }^{1}$, Tetiana I. Bakhur ${ }^{2 *}$, \\ Oksana A. Zghozinska ${ }^{1}$, and Vasyl S. Rusak ${ }^{3}$ \\ ${ }^{1}$ Department of Parasitology, Veterinary-Sanitary Expertise and Zoohygiene, Faculty of Veterinary Medicine, \\ Polissia National University, Ukraine \\ ${ }^{2}$ Department of Parasitology and Pharmacology, Faculty of Veterinary Medicine, Bila Tserkva National Agrarian \\ University, Bila Tserkva, Ukraine \\ ${ }^{3}$ Department of internal animal diseases and physiology, Faculty of Veterinary Medicine, Polissia National \\ University, Zhytomyr, Ukraine
}

CHALA, I. V., D. V. FESHCHENKO, O. A. DUBOVA, T. I. BAKHUR, O. A. ZGHOZINSKA, V. S. RUSAK: Changes in the lipid profile of neutered cats' blood in cases of obesity and diabetes. Vet. arhiv 91, 635-645, 2021.

\section{ABSTRACT}

The aim of the present study was to examine the lipid profile, lipid fractions and the lipid peroxidation state in the blood of neutered cats with obesity and diabetes. Three groups of neutered cats (males and females) were formed for the study. We compared cats with obesity (7-9 points on a 9-point BCS scale), with obesity complicated by diabetes, and clinically healthy animals with normal body condition scores (4-5 BCS points). Lipidogram parameters, fractions of high-density lipoprotein (HDL), low-density lipoprotein (LDL) and very low-density lipoprotein (VLDL), chylomicrons (CM), lipid peroxidation products (POL) - lipid hydroperoxides (GPL) and malondialdehyde (MDA) were analysed. In obese cats, a decrease in HDL and phospholipids was observed, and an increase in LDL, VLDL, CM, triglycerides, and cholesterol. No significant differences in lipid and lipoprotein metabolism between neutered females and males were found. A tendency towards increasing concentrations of lipoproteins, triglycerides and cholesterol in males, as well as an increase in phospholipids in females was found. In cats with obesity and associated diabetes, the ratio of phospholipids: cholesterol was less than one, while in healthy cats - more than one. Obesity and diabetes initiate POL and increased concentrations of GPL and MDA, which were the highest in the blood of females with associated pathology.

Key words: cat; obesity; triglycerides; cholesterol; phospholipids; lipid hydroperoxides

\section{Introduction}

Obesity in domestic cats has recently become an urgent problem in veterinary medicine. According to O'CONNELL et al. (2018), $16-63 \%$ of cats 5 years old and more are overweight. The causes of this pathology are various: keeping animals in an urban environment (COLLIARD et al., 2009), hypodynamia, unlimited access to food, and sterilization (HOENIG, 2014). Obesity in cats may be accompanied by concomitant diseases of the skin, and the urinary and musculoskeletal systems (ALLAN et al., 2000; BACKLUND et al., 2011; MARINO et al., 2014).

\footnotetext{
*Corresponding author:

Tetiana Bakhur, PhD, Faculty of Veterinary Medicine, Bila Tserkva National University, Soborna Sq.8/1, Bila Tserkva, Kyiv region, Ukraine, Phone: +38 09830578 13; E-mail: fly_13@ukr.net
} 
Diabetes occurs as an independent pathology or as a consequence of obesity. According to statistics, the probability of diabetes developing in an obese cat is four times higher than in animals with normal body weight (HENSON and O'BRIEN, 2006; LOFTUS and WARKSHLAG, 2015). Over the past thirty years, the number of diabetes cases in cats at veterinary practices has increased 15 times (GOTTLIEB and RAND, 2018).

The vast majority of cats with diabetes associated with obesity are neutered males, where the change in hormonal status is directed towards the accumulation of lipids in the fat depot and reduced protein synthesis (LARSEN, 2017).

Hyperglycemia and hyperlipemia are the components of a single pathology, known as metabolic syndrome (VERBRUGGHE and BAKOVIC, 2013), in which changes in lipid metabolism occur (BUTTERWICK et al., 2001; ZORAN, 2010). Lipids are found in the blood in the form of lipoproteins - complexes of triglycerides, cholesterol, phospholipids and stabilizing proteins. Blood lipoproteins are divided into fractions: high density lipoproteins (HDL), low density lipoproteins (LDL), very low density lipoproteins (VLDL) and chylomicrons (CM) (JERICO et al., 2009). Cholesterol is contained in each fraction of the lipoproteins, but its metabolism differs significantly. Cholesterol from HDL is used to build cell membranes and synthesizable acids. LDL and VLDL cholesterol penetrate the intima of blood vessels and change their structure (reducing elasticity), causing an atherogenic effect (FORTI and DIAMENT, 2006).

In the blood of cats, in contrast to humans, the content of HDL predominates (DEMACKER et al., 1987). Obesity, diabetes and changes in hormonal status in neutered cats significantly change the ratio of lipoprotein fractions, increasing the proportion of LDL and VLDL. This creates the preconditions for the development of atherosclerosis and coronary heart disease (BAILHACHE et al., 2003; FUJIWARA et al., 2015).

Obesity and diabetes initiate the formation of reactive oxygen species. Free radicals accelerate the reactions of lipid peroxidation (POL), the formation of lipid hydroperoxides (GPL), and malonic dialdehyde (MDA). POL is most active the in cell membranes. Modification of membrane lipids disrupts the transport of substances, and changes the cells' sensitivity to humoral regulators, which complicates the primary disease (KAWASUMI et al., 2018). Therefore, the possibility exists that the findings of this research, the lipid blood profile in cats, could be used in more comprehensive assessment of feline patients with diabetes, influence their therapy or predict its effectiveness.

The aim of the study was to examine changes in the lipid profile, blood lipid fractions and POL products in neutered cats of different sexes with obesity and obesity-associated diabetes.

\section{Materials and methods}

Animals and experimental design. The research was conducted in the laboratories of the Polissia National University. A total of 30 neutered domestic cats aged 5-9 years, short-haired breeds (British and European short-haired, Siamese) or their crossbreeds were used, which were sent to the university clinic for routine medical examinations. The animals were divided into 3 groups on the principle of: 1) the presence of obesity; 2) obesity + diabetes; 3 ) healthy cats (Table 1).

Previously, according to the standard protocol of the clinical examination, the presence of parasites, infections and other pathologies in cats was excluded.

For 14 days before the procedure of taking representative blood samples, all cats $(n=30)$ kept at home were provided with a standardized diet: canned "Purina Felix Fantastic with chicken in jelly" food and unrestricted water. Outpatient observation of the animals was over three days. The presence of obesity was established after visual-analogue evaluation of body parameters on a 9-point BCS scale.

Serum and plasma samples. Blood samples were taken from the animals from the Vena cephalica antebrachii on an empty stomach two days in a row, starting from 14 days after the formation of the experimental groups. The duration of fasting was 12 hours. 
I. V. Chala et al.: Changes in the lipid profile of neutered cats' blood in cases of obesity and diabetes

Table 1. Division principles of experimental animals into groups

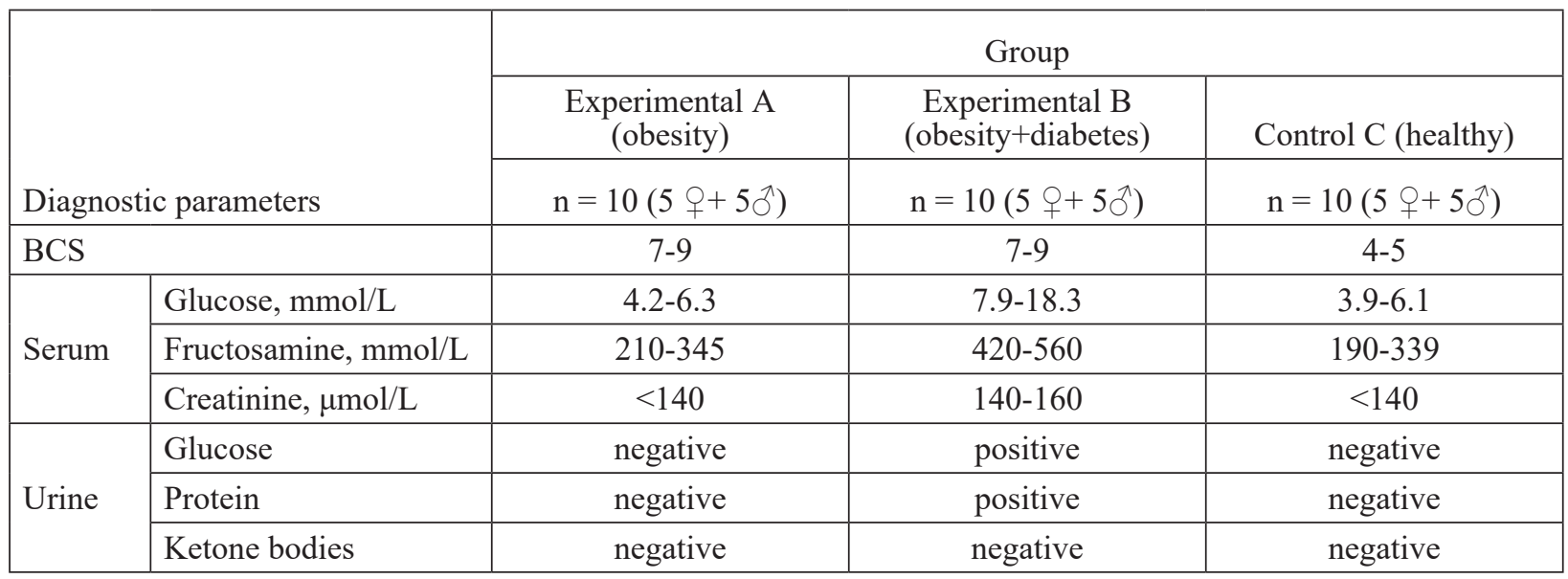

Note: BCS-body condition score is 9 points

Blood samples were taken in vacuum tubes with an EDTA stabilizer, and the resulting plasma was immediately cooled to $4{ }^{\circ} \mathrm{C}$. Plasma samples were used to determine the concentration of lipoproteins and their fractions, GPL and MDA.

Serum samples were used to determine the concentration of glucose, fructosamine, creatinine, cholesterol, phospholipids and triglycerides.

Urine samples. Urine samples were taken in the morning before feeding using a urethral catheter for cats $1 \times 130 \mathrm{~mm}$ (Kruuse, Denmark), and the standard volume was used for the study. The presence and content of glucose, protein, ketone bodies in the urine were determined using H11MA Urine Strips (Dirui Industrial Group Co., Ltd, China).

Analytical procedures. Glucose and fructosamine concentrations were determined in serum samples to confirm diabetes mellitus. Creatinine content was determined in serum samples to detect concomitant chronic renal pathology.

Most of the cats admitted to the study had creatinine levels consistent with healthy animals. Some individuals reached values of $160 \mu \mathrm{mol} / \mathrm{L}$, corresponding to the stage of mild azotemia, according to the IRIS classification (International Renal Interest Society). To determine the fractions of lipoproteins, plasma samples were centrifuged in a solution with a density of $1.063 \mathrm{~g} / \mathrm{mL}$. The LDL were precipitated with heparin and manganese chloride. The HDL remained in solution, and $\mathrm{CM}$ formed a film on the surface, which was removed. Lipoprotein fractions were separated by differentiated polyacrylamide gel electrophoresis with a $\mathrm{pH}$ of 8.9 . Three layers of gel with a PAAG concentration of 10,5 and $3 \%$ were used to separate the lipoproteins.

The GPL concentration was determined using a Mapoda UV-1800 spectrophotometer (Shangai Mapoda Instruments Co., Ltd, China) (wavelength $\lambda=232 \mathrm{~nm}$, UV spectra). The plasma lipid fraction was extracted in isopropanol-heptane (1:1) for one hour, the mixture was acidified with hydrochloric acid and distilled heptane was added.

The concentration of MDA (TBA-active product) was also determined in the plasma spectrophotometrically (wavelength $\lambda=550 \mathrm{~nm}$ ). A mixture of plasma samples with orthophosphate and thiobarbituric acids (0.5\%) was preliminarily incubated in a water bath, cooled, then n-butane was added and it was centrifuged.

The concentration of glucose, total cholesterol and creatinine was determined using a semiautomatic biochemical analyser Chem 7 (Erba, Czech Republic) with a line of reagents from DAC (Republic of Moldova).

The concentration of triglycerides was determined by an enzymatic colorimetric method (PAP) using a set of reagents from the company "Diagnosticum" (Hungary), "Triglycerides PAP". 
The concentration of phospholipids was determined by extraction of the lipid fraction with isoamyl alcohol, and subsequent mineralization. Inorganic phosphorus in interaction with ammonium molybdate forms phosphomolybdic acid, the optical density of which was measured at a wavelength of $\lambda=630 \mathrm{~nm}$.

The concentration of fructosamine was determined by a set of reagents from Sentinel (Italy), Fructosamine 17350HS and Fructosamine Ctr1, 16353.

Statistical evaluation of the results. The results obtained were statistically processed using Statistica 13.3 software, the data were checked for normal distribution using the Distribution Fitting module. We determined the arithmetic mean, the standard error of the mean, and as in the studies $n$ $=10$, the calculations were performed according to the formulas for a small sample. To assess the equality of regressions, Fisher's test (ANOVA) was determined for a significance level of 0.05 . To test the hypothesis of consistency between the indicators of healthy animals and animals of the experimental groups, $\chi 2$ (Pearson's consistency criterion) was determined for a significance level of 0.05 .

\section{Results}

Analysis of the plasma lipoprotein spectrum of healthy neutered cats (Control group C) showed that the concentration of HDL exceeded other fractions of lipoproteins; the lower the density of lipoproteins, the lower the values of their concentration (Table 2). In males, the concentrations of all lipoprotein fractions were higher than in females $(P>0.05)$ (Fig. 1-4). Also in healthy males, the concentration of triglycerides and cholesterol was slightly higher than in females. However, the concentration of phospholipids and their ratio to the cholesterol were higher in females $(\mathrm{P}>0.05)$ (Table 3, Fig. 5).

In cats with obesity and associated diabetes (groups A and B), the concentration of all fractions of lipids (triglycerides, cholesterol and phospholipids) was higher than in healthy animals (group C).

The content of POL products in sick cats of both experimental groups exceeded those in the control group, where the concentration of GPL and MDA was lower in males compared to females $(\mathrm{P}>0.05)$ (Table 4).
In obese cats (group A) compared to healthy animals, some changes in the concentration of the lipoprotein fractions were observed. In particular, the concentration of HDL was lower than that of the control analogues and the differences were statistically significant by the criterion $\chi^{2}$ $(\mathrm{P}<0.05)$. The concentration of other lipoprotein fractions in obese cats had increased compared to that in the control animals. The degree of increase in the content of different fractions varied. The most significant differences were found in the concentrations of $\mathrm{CM}$ and LDL $(\mathrm{P}<0.05)$. The difference in the concentration of VLDL in males and females of group A differed significantly from the corresponding values in the control. However, comparisons of VLDL concentrations between groups $\mathrm{A}$ and $\mathrm{C}$ (males + females) showed high variance $(\mathrm{P}>0.05)$ (Table 2$)$. In general, in obese males, the concentrations of all the studied fractions of lipoproteins exceeded those in females $(\mathrm{P}>0.05)$. The largest differences were found in the content of VLDL, the smallest in the content of CM (Fig. 1-4).

Also, in obese cats there was an increase in the concentrations of cholesterol $(\mathrm{P}>0.05)$ and triglycerides $(\mathrm{P}<0.05)$, as well as a decrease in the concentration of phospholipids ( $\mathrm{P}>0.05)$ (Table 3$)$. Males in group A had higher cholesterol content and lower content of phospholipids compared to the females. Such changes significantly affected the ratio of phospholipids to cholesterol. In general, in the group it was less than 1 and half as much as in the animals in the control group $\mathrm{C}(\mathrm{P}<0.05)$. In males, this ratio was lower than in females $(\mathrm{P}>0.05)$ (Fig. 5).

The concentration of GPL and MDA in obese cats was higher than in healthy cats $(\mathrm{P}>0.05)$. A significant increase in the concentration of MDA was recorded in females in group $\mathrm{A}$, compared with the control analogues $(\mathrm{P}<0.05)$. In females, the concentration of both POL products was higher than that of males $(\mathrm{P}>0.05)$ (Table 4).

In cats with obesity and diabetes mellitus (group B), the concentration of HDL was lower than in group $\mathrm{A}$ and the control $(\mathrm{P}>0.05)$. But in females in group $\mathrm{B}$ this indicator slightly exceeded the value in males $(\mathrm{P}>0.05)$. 
I. V. Chala et al.: Changes in the lipid profile of neutered cats' blood in cases of obesity and diabetes

Table 2. Lipoprotein concentrations of various densities in the blood plasma of cats, $\mathrm{mg} / 100 \mathrm{~mL}, \mathrm{M} \pm \mathrm{m}$

\begin{tabular}{|c|c|c|c|c|c|}
\hline \multicolumn{2}{|l|}{ Group of animals } & HDL x 10 & LDL & VLDL & $\mathrm{CM}$ \\
\hline \multirow{3}{*}{$\begin{array}{l}\text { Experimental A } \\
\text { (obesity) }\end{array}$} & $\mathrm{n}=10$ & $38.3 \pm 1.31^{*}$ & $81.6 \pm 3.05^{* \ddagger}$ & $34.1 \pm 2.54^{*}$ & $14.5 \pm 1.52^{*}$ \\
\hline & $\lambda \cdot n=5$ & $39.7 \pm 1.69$ & $86.4 \pm 3.34^{*}$ & $36.2 \pm 1.58^{* *}$ & $14.8 \pm 1.0^{*}$ \\
\hline & $\stackrel{\circ}{+} \cdot \mathrm{n}=5$ & $36.2 \pm 2.07^{*}$ & $74.9 \pm 4.58$ & $31.1 \pm 2.74^{\ddagger *}$ & $14.2 \pm 1.87^{*}$ \\
\hline \multirow{3}{*}{$\begin{array}{l}\text { Experimental B } \\
\text { (obesity+diabetes) }\end{array}$} & $\mathrm{n}=10$ & $36.8 \pm 1.41^{*}$ & $84.8 \pm 2.86^{* \neq}$ & $37.4 \pm 3.92^{\ddagger *}$ & $13.4 \pm 1.91^{*}$ \\
\hline & $\hat{\sigma} \cdot n=5$ & $34.6 \pm 3.39^{*}$ & $87.7 \pm 4.46^{*}$ & $39.9 \pm 3.20^{* \neq}$ & $12.9 \pm 1.59^{*}$ \\
\hline & $q \cdot n=5$ & $39.0 \pm 1.26^{\ddagger}$ & $81.9 \pm 4.02$ & $34.8 \pm 3.90^{* \neq}$ & $13.9 \pm 1.22^{*}$ \\
\hline \multirow{3}{*}{$\begin{array}{l}\text { Control C } \\
\text { (healthy) }\end{array}$} & $\mathrm{n}=10$ & $40.8 \pm 1.33$ & $70.1 \pm 3.07$ & $28.5 \pm 1.15$ & $8.0 \pm 0.86$ \\
\hline & $\lambda \cdot n=5$ & $41.6 \pm 1.83$ & $72.5 \pm 4.70$ & $30.9 \pm 1.06$ & $8.9 \pm 1.24$ \\
\hline & $q \cdot n=5$ & $39.9 \pm 2.32$ & $68.4 \pm 4.52$ & $25.3 \pm 2.31$ & $6.9 \pm 1.17$ \\
\hline
\end{tabular}

$\neq$ - statistically significant difference between the indicators of the control and experimental groups according to the Fisher criterion; $\mathrm{P}<0.05$; * - the difference between the indicators of the control and experimental groups for $\chi^{2}$ is significant at $\mathrm{P}<0.05$

Table 3. The cats' serum lipid fractions, $\mathrm{M} \pm \mathrm{m}, \mathrm{mmol} / \mathrm{L}$

\begin{tabular}{|c|c|c|c|c|}
\hline \multicolumn{2}{|l|}{ Group of animals } & Cholesterol & Triglycerides & Phospholipids \\
\hline \multirow{3}{*}{$\begin{array}{l}\text { Experimental A } \\
\text { (obesity) }\end{array}$} & $\mathrm{n}=10$ & $3.82 \pm 0.466$ & $1.23 \pm 0.109^{\ddagger}$ & $2.21 \pm 0.238$ \\
\hline & $\pi \cdot n=5$ & $4.02 \pm 0.378$ & $1.23 \pm 0.092^{\ddagger}$ & $2.04 \pm 0.198$ \\
\hline & 우. $\mathrm{n}=5$ & $3.54 \pm 0.307$ & $1.23 \pm 0.208^{\ddagger}$ & $2.43 \pm 0.230$ \\
\hline \multirow{3}{*}{$\begin{array}{l}\text { Experimental B } \\
\text { (obesity+diabetes) }\end{array}$} & $\mathrm{n}=10$ & $3.73 \pm 0.197$ & $1.62 \pm 0.164^{* \neq}$ & $2.75 \pm 0.121$ \\
\hline & $\lambda \cdot n=5$ & $3.79 \pm 0.312$ & $1.63 \pm 0.174^{\ddagger}$ & $2.66 \pm 0.210$ \\
\hline & ㅇ․ $\mathrm{n}=5$ & $3.68 \pm 0.313^{\ddagger}$ & $1.60 \pm 0.123$ & $2.83 \pm 0.159$ \\
\hline \multirow{3}{*}{$\begin{array}{l}\text { Control C } \\
\text { (healthy) }\end{array}$} & $\mathrm{n}=10$ & $2.47 \pm 0.352$ & $0.67 \pm 0.078$ & $2.82 \pm 0.567$ \\
\hline & $\delta \cdot n=5$ & $2.66 \pm 0.212$ & $0.73 \pm 0.048$ & $2.80 \pm 0.268$ \\
\hline & $q . \mathrm{n}=5$ & $2.2 \pm 0.15$ & $0.58 \pm 0.048$ & $2.84 \pm 0.118$ \\
\hline
\end{tabular}

$*-\chi^{2}$ for indicators of control and experimental groups is more than critical if $\mathrm{P}<0.05$; $\neq$ - statistically significant difference between the indicators of the control and experimental groups according to the Fisher criterion $\mathrm{P}<0.05$

Table 4. Concentrations of GPL and MDA in the plasma of cats, $\mathrm{M} \pm \mathrm{m}$

\begin{tabular}{|c|c|c|c|}
\hline \multicolumn{2}{|l|}{ Group of animals } & GPL, units & $\mathrm{MDA}, \mu \mathrm{mol} / \mathrm{L}$ \\
\hline \multirow{3}{*}{$\begin{array}{l}\text { Experimental A } \\
\text { (obesity) }\end{array}$} & $\mathrm{n}=10$ & $3.72 \pm 0.457$ & $2.76 \pm 0.191$ \\
\hline & o. $n=5$ & $3.54 \pm 0.254$ & $2.63 \pm 0.247$ \\
\hline & q. $\mathrm{n}=5$ & $3.89 \pm 0.266$ & $2.88 \pm 0.343^{\ddagger}$ \\
\hline \multirow{3}{*}{$\begin{array}{l}\text { Experimental B } \\
\text { (obesity+diabetes) }\end{array}$} & $\mathrm{n}=10$ & $4.82 \pm 0.262^{\mathrm{L} \neq}$ & $3.32 \pm 0.360^{\ddagger \mathrm{L}}$ \\
\hline & ก. $n=5$ & $4.52 \pm 0.428$ & $3.09 \pm 0.589^{\ddagger}$ \\
\hline & P. $n=5$ & $5.12 \pm 0.403$ & $3.55 \pm 0.532^{\ddagger}$ \\
\hline \multirow{3}{*}{$\begin{array}{l}\text { Control C } \\
\text { (healthy) }\end{array}$} & $\mathrm{n}=10$ & $3.04 \pm 0.239$ & $1.55 \pm 0.080$ \\
\hline & ก. $n=5$ & $2.86 \pm 0.416$ & $1.40 \pm 0.066$ \\
\hline & Q. $\mathrm{n}=5$ & $3.12 \pm 0.208$ & $1.70 \pm 0.129$ \\
\hline
\end{tabular}

$\neq$ - the difference between the control and experimental; ${ }^{\mathrm{L}}$ - the difference between the experimental groups according to the Fisher criterion is significant at the level of $\mathrm{P}<0.05$ 


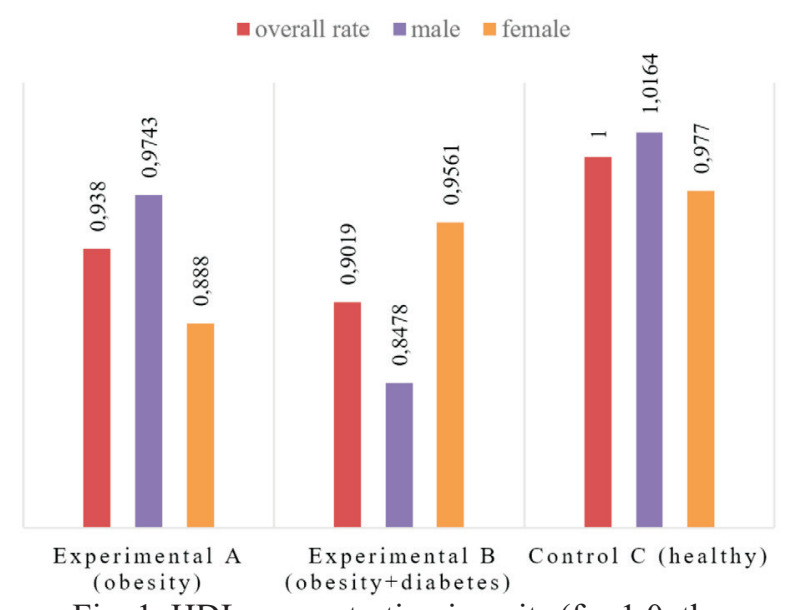

Fig. 1. HDL concentration in units (for 1.0, the concentration in group $\mathrm{C}$ is assumed)

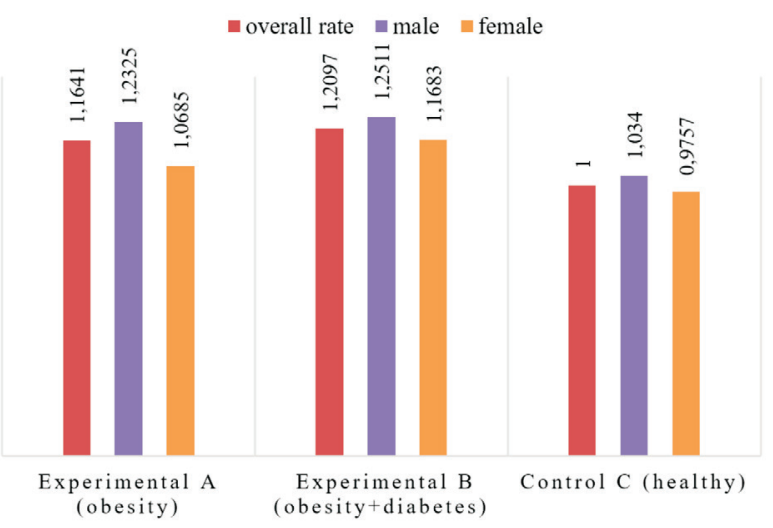

Fig. 2. LDL concentration in units. a. (for 1.0, the concentration in group $\mathrm{C}$ is assumed)

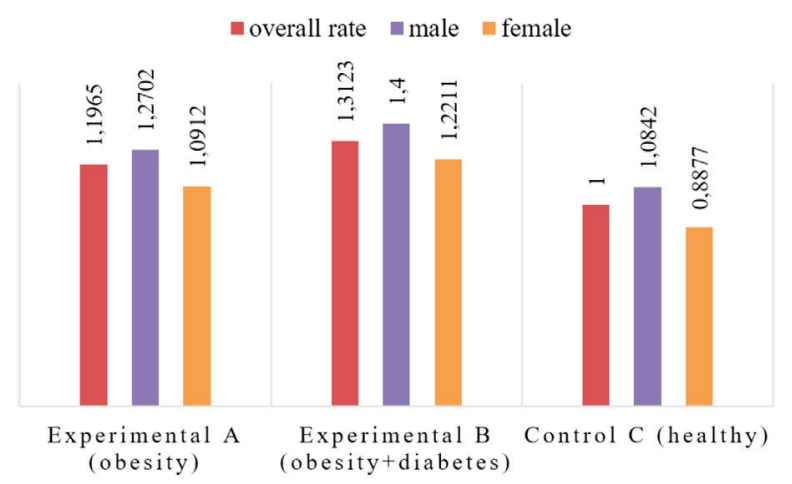

Fig. 3. VLDL concentration in units (for 1.0, the concentration in group $\mathrm{C}$ is assumed)

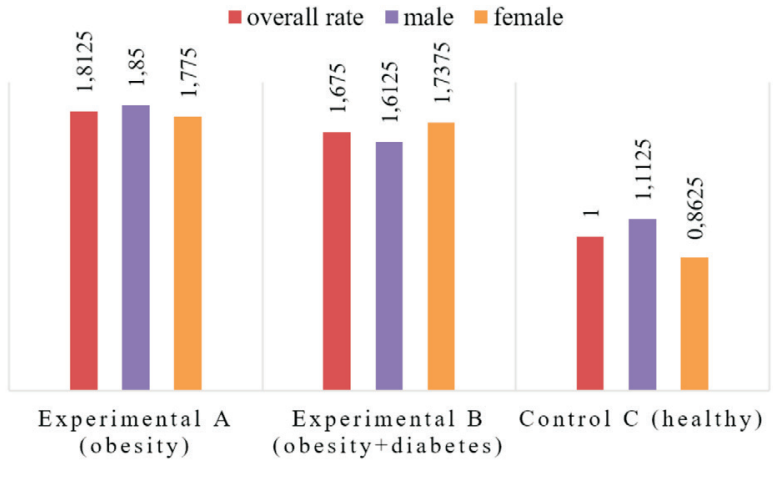

Fig. 4. CM concentration in units (for 1.0, the concentration in group $\mathrm{C}$ is assumed)

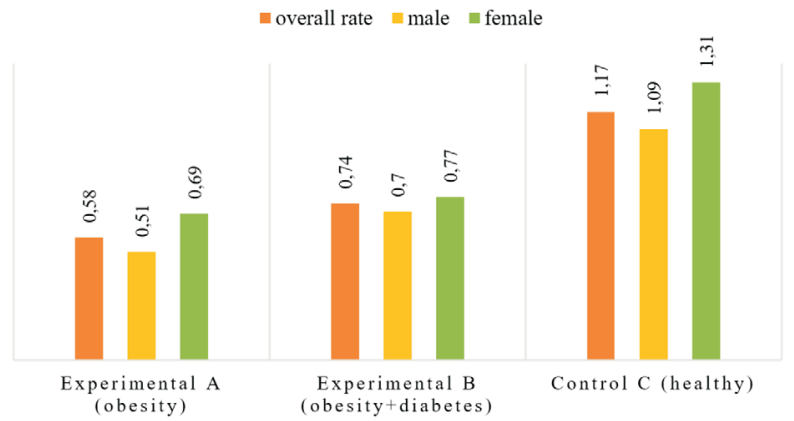

Fig. 5. The relationship between the concentrations of phospholipids and cholesterol 
In animals with associated pathology, the content of LDL and VLDL fractions exceeded that of healthy cats $(\mathrm{P}<0.05)$ and cats from group A $(P>0.05)$. In females, the content of LDL and VLDL was higher than that of males $(p>0.05)$. The concentration of $\mathrm{CM}$ in cats in group $\mathrm{B}$ was higher than that of healthy cats $(\mathrm{P}<0.05)$ and lower than in cats with only obesity from group $\mathrm{A}(\mathrm{P}>0.05)$ (Table 2). In females of group B the concentration of $\mathrm{CM}$ was higher than in males, and twice as high as in healthy females in group $\mathrm{C}(\mathrm{P}<0.05)$ (Fig. 4).

In the study of lipid fractions in the cats in group $\mathrm{B}$, it was found that the cholesterol content of obese and diabetic animals was in an intermediate position: its concentration was just higher than in healthy animals and lower than in cats with obesity $(\mathrm{P}>0.05)$. The concentration of cholesterol in group B was slightly higher in males compared to females $(\mathrm{P}>0.05)$. However, there was a significant difference between females in groups $\mathrm{B}$ and $\mathrm{C}$ $(\mathrm{P}<0.05)$. The content of triglycerides in cats in group $B$ exceeded that in groups $A$ and $C(P<0.05)$. In males with associated pathology, the concentration of triglycerides exceeded that of similar females and healthy males from group $\mathrm{C}(\mathrm{P}<0.05)$ (Table 3$)$. The concentration of phospholipids in the members of group B was lower than in the control group and higher than in cats in group $\mathrm{A}(\mathrm{P}>0.05)$. Females were characterized by slightly higher values of phospholipid content than males $(\mathrm{P}>0.05)$.

The ratio between phospholipids and cholesterol in the blood of cats in group $\mathrm{B}$ also had intermediate values: less than in group $\mathrm{C}(\mathrm{P}<0.05)$ and more than in group $\mathrm{A}(\mathrm{P}>0.05)$. The values of this coefficient almost did not differ at all between animals of different sexes (Fig. 5).

The concentration of GPL and MDA in cats in group B was the highest among the studied animals (Table 4), and differed significantly from the indicators of groups $\mathrm{A}$ and $\mathrm{C}(\mathrm{P}<0.05)$. Higher values were measured for both parameters in group $\mathrm{B}$ for females than for males $(\mathrm{P}>0.05)$. A significant difference in the value of the concentrations of GPL and MDA was recorded between females in groups $\mathrm{B}$ and $\mathrm{C}(\mathrm{P}<0.05)$.

\section{Discussion}

The lipid and lipoprotein profiles of healthy neutered cats. A specific feature of Felis silvestris catus (Linnaeus, 1758) is the dominance of the HDL fraction in the lipid profile (DEMACKER et al., 1987). The present study showed that, even after neutering cats, HDL does not lose its dominant position. In healthy neutered males, the content of all lipoprotein fractions was slightly higher than in females.

Males also tended to have higher triglyceride and cholesterol levels, with a significant increase in VLDL. Probably the intensive synthesis of these metabolites by de novo enzyme systems is characteristic of the neutered cat's body (USUI et al., 2015).

In females, a predominant concentration of phospholipids was noted. These differences were recorded within the statistical error. The rather low level of atherogenic process development in neutered cats was evidenced by the high ratio of phospholipids to cholesterol (ALLAN et al., 2000, COLLIARD et al, 2009). After all, phospholipids play an important role in stabilizing lipoprotein membranes, transporting cholesterol and its inclusion in subsequent metabolic processes (SHOVELLER et al., 2016). The low concentration of POL products (GPL and MDA), with higher values in females, indicates the absence of marked oxidative stress in the body of sexually inactive animals (CHALA et al., 2018, PRASENJIT and SUSHIL, 2015).

The lipid and lipoprotein profiles of neutered cats with obesity. Obesity is a risk factor for cats after being neutered (LARSEN, 2017), as it not only causes the accumulation of triglycerides in the fat depot, but also leads to significant changes in all parts of the metabolism (ZORAN, 2010). In the experiment, obesity caused a slight decrease in the concentration of HDL in the cats' blood. This may have been due to a decrease in the concentration of phospholipids, which make up a significant proportion of HDL (FORTI and DIAMENT, 2006). The concentrations of LDL, VLDL and CM fractions, in contrast, exceeded those of healthy cats. These data are consistent with other studies 
(BAILHACHE et al., 2003; JORDAN et al., 2008). The degree of increase in the concentration of fractions correlated with a decrease in their density, which is a sign of a recorded increase in triglycerides in the blood of obese cats (WATSON, 1996). The maximum difference between healthy and obese cats was observed in the CM content. This fraction of lipoproteins consists of $85 \%$ triglycerides and serves as a transport medium in tissues (JEUSETTE et al., 2005). CM is also rich in cholesterol and its esters (TAKAHARA et al., 2013). Thus, obese cats had an increase in lipoprotein fractions rich in triglycerides and cholesterol. The concentration of cholesterol was the highest among all studied groups of animals, but the ratio of the phospholipid concentration to cholesterol was minimal. The data obtained correspond to the results of HOENIG et al. (2003).

In obese males the concentration of all lipoprotein fractions was higher than in females. However, these differences are not the same for different fractions: HDL values differed the least. Quite significant gender fluctuations were observed with respect to $\mathrm{LDL}$ and $\mathrm{CM}$ concentrations, and the largest with respect to VLDL. No gender differences were observed in triglyceride concentrations, but cholesterol levels in obese males were higher than in females. The results obtained require further research because BUTTERWICK et al. (2001) determined that the concentration of cholesterol was influenced more by the age of the animal than by sex. At the same time, the current study corresponds to the data of TARKOSOVA et al. (2016), who claimedthat it is overweight which determines the metabolism of cholesterol and triglycerides. The data of these researchers are consistent with our results regarding the increased concentration of POL products in obese cats of both sexes, compared with healthy animals. Moreover, the intensity of the accumulation of GPL and MDA is more dynamic in females.

The lipid and lipoprotein profiles of neutered cats with obesity and diabetes. Overweight cats are often prone to developing diabetes (FEITOSA et al., 2016; CHANDLER et al., 2017). Obesity leads to functional changes in the endocrine system, which reduces the sensitivity of cells to insulin and reduces its synthesis (BAILHACHE et al., 2003; VERBRUGGHE and HESTA, 2017). In terms of pathophysiological changes, the clinical signs of diabetes in cats are similar to type 2 in humans (HOENIG, 2012; HOENIG, 2014). According to our findings, the blood of obese cats with associated diabetes mellitus is classically dominated by the HDL fraction, and the share of "atherogenic" fractions of LDL and VLDL were the lowest of all lipoproteins. These phenomena are more characteristic of females. At the same time, the concentration of VLDL in cats with compatible pathologies exceeded that in healthy cats by almost a third. The priority content of lipoprotein fractions with a high content of triglycerides and the socalled "bad" cholesterol indicates the progressive accumulation of dangerous cholesterol fractions due to the development of diabetes (MORI et al., 2011; MORI et al., 2015). Cholesterol metabolism disorders are an additional stress for the liver and other organs (JORDAN et al., 2008; HOENIG et al., 2010). Importantly, the gender differences in LDL were smaller than in obese cats, and slightly greater than in healthy ones. It is possible that disorders of carbohydrate metabolism partially compensate for the changes caused by the decrease in the concentration of sex hormones.

The observed decrease in the CM in cats with complicated diabetes, compared to cats with only obesity, may be associated with inhibition of intestinal triglyceride resynthesis in conditions of insulin deficiency. Due to the disruption of the incorporation of triglycerides into the adipose tissue, their total amount in the blood of cats with diabetes exceeded the results in the other groups. The concentration of the CM in females was slightly higher than in males.

The elevated levels of phospholipids in the blood of obese and diabetic cats may be due to an increase in the proportion of lysophospholipids, as reported by GOTTLIEB and RAND (2018). The concentration of triglycerides was also the highest among the studied animals. These data, together with the results of lipoprotein analysis, indicate possible disturbances in the hepatic transformation of LDL and VLDL, and a high risk of atherogenic 
events due to diabetes. Similar findings were presented by HENSON and O`BRIEN (2006).

Females with diabetes had a higher content of phospholipids in their blood than the analogous males. In contrast, males had greater concentrations of triglycerides and cholesterol. Such changes indicate the reduced intensity of phospholipid metabolism in neutered males (HOENIG et al., 2003). However, the significant variance of these indicators does not allow us to draw an unambiguous conclusion about gender differences in the fractional distribution of lipids.

Diabetes mellitus in cats exacerbates the pathological changes in lipid metabolism caused at the stage of obesity (PAZAK et al., 1998; OKADA et al., 2017). However, the differences between obese animals and individuals with obesity complicated by diabetes are smaller than between healthy and obese cats. This may indicate certain adaptive mechanisms that occur in obese animals, because diabetes has developed as a secondary pathology (TARKOSOVA et al., 2016; PHILIPS et al., 2017).

Excess glucose and lipids are considered to be one of the leading factors that cause dysfunction of pancreas $\beta$-cells (PRASENJIT and SUSHIL, 2015). Insulin-synthesizing cells are characterized by a limited set of genes to encode the expression of the antioxidant system's components (DE GODOY and SWANSON, 2014). The consequence of such changes is the intensification of the formation of reactive oxygen species and the development of POL (PRASENJIT and SUSHIL, 2015). In the present study, the combined course of obesity and diabetes led to an increase in the concentration of POL products (GPL and MDA). Cats with an associated pathology had the highest values of both indicators, which differed significantly from healthy animals and cats with obesity but without diabetes. In contrast to lipid fractions, the concentration of POL products was higher in females than in males. Thus, obesity associated with diabetes leads to ultra-high intensity of POL. Some studies show that modified forms of lipids, in particular fatty acid peroxides, lead to pathological changes in membranes and the development of ischemic pathology (MORI et al., 2015).

\section{Conclusions}

The results of this study show that the blood of neutered obese cats is characterized by increased concentrations of LDL, VLDL, CM, triglycerides and cholesterol, but reduced levels of HDL and phospholipids. Diabetes mellitus, as a secondary pathology, did not exacerbate the existing disorders in the lipid profile of cats, recorded at the stage of obesity. The exception is the increasing concentration of triglycerides, which indicates a violation of their metabolism with the development of diabetes. These changes in males were more intense than in females. Obesity and diabetes intensified the POL processes. These pathologies led to the accumulation in the blood of POL products: GPL and MDA. Maximum concentrations were found in obese females with associated diabetes mellitus.

\section{References}

ALLAN, F. J., D. U. PFEIFFER, B. R. JONES, D. H. B. ESSLEMONT, M. S. WISEMAN (2000): A cross-sectional study of risk factors for obesity in cats in New Zealand. Prev. Vet. Med. 46, 183-196.

DOI: $10.1016 / \mathrm{S} 0167-5877(00) 00147-1$

BACKLUND, B., D. L. ZORAN, M. B. NABITY, B. NARBY, J. E. BAUER (2011): Effects of dietary protein content on renal parameters in normal cats. J. Feline Med. Surg. 13, 698-704.

DOI: 10.1016/jfms.2011.05.019

BAILHACHE, E., P. NGUYEN, M. KREMPF, B. SILIART, T. MAGOT, K. OUGUERRAM (2003): Lipoproteins abnormalities in obese insulin-resistant dogs. Metabolism: Clinic. Exp. 52, 559-564.

DOI: $10.1053 /$ meta.2003/50110

BUTTERWICK, R. F., M. MC CONNELL, P. J. MARKWELL, T. D. WATSON (2001): Influence of age and sex on plasma lipid and lipoprotein concentrations and associated enzyme activities in cats. American J. Vet. Res. 62, 331-336.

DOI: 10.2460/ajvr.2001.62.331

CHALA, I., V. RUSAK, L. CHUPRUN, P. KOVALYOV (2018): The Lipids peroxidation and some biological indexes of blood in cats with liver diseases. Anim. Biol. 20, 89-96 (in Ukrainian).

DOI: 10.15407/animbiol20.02.089.

CHANDLER, M., S. CUNNINGHAM, E. M. LUND, C. KHANNE, R. NARAMORE, A. PATEL, M. J. DAY (2017): Obesity and associated comorbidities in people and companion animals: a one health perspective. J. Comp. Pathol. 156, 296-309.

DOI: 10.1016/j.jcpa.2017.03.006 
COLLIARD, L., B. M. PARAGON, B. LEMUET, J. J. BÈNET, G. BLANCHARD (2009): Prevalence and risk-factors of obesity in an urban population of healthy cats. J. Feline Med. Surg. 11, 135-140.

DOI: $10.1016 /$ j.jfms.2008.07.002

DE GODOY, M. P. S., K. S. SWANSON (2014): Companion animals simposium: Nutrigenomics: Using gene expression and molecular biology data to understand pet obesity. J. Anim. Sci. 91, 2949-2964.

DOI: $10.2527 /$ jas.2012-5860

DEMACKER P. N. M., VAN HEIJST P. J., HAK-LEMMERS H. L. M., STALENHOEV A. F. H. (1987): A study of the lipid transport system in the cat Felix domesticus. Atherosclerosis 66, 113-123.

DOI: $10.1016 / 0021-9150(87) 90186-9$

FEITOSA, M. L., S. F. ZANINI, D. R. DE SOUSA, E. FANTUZZI, T. C. L. CARRARO, C. A. PINTO, R. M. BERTONCELI, G. L. COLNAGO (2016): Glucose and lipid profile of obese dogs fed with different starchy sources. J. Ciệncia Rural 46, 2189-2194.

DOI: $10.1590 / 0103-8478 \mathrm{cr} 20151327$

FORTI, N., J. DIAMENT (2006): High-density lipoproteins: metabolic, clinical, epidemiological and therapeutic intervention aspects. An update for clinicians. Arq. Bras. Cardiol. 87, 671-679.

DOI: 10.1590/S0066-782X2006001800019

FUJIWARA, M., N. MORI, T. SATO, H. TASAKI, S. ISHIKAWA, I. YAMAMOTO, T. ARAI (2015): Changes in fatty acid composition in tissue and serum of obese cat fed a high fat diet. J. BMC Vet. Res. 11, 200.

DOI: $10.1186 / \mathrm{s} 12917-015-0519-1$

GOTTLIEB, S., J. RAND (2018): Managing feline diabetes: current perspective. J. Vet. Med. Res. Rep. 9, 33-42. DOI: $10.2147 /$ VMRR.S125619

HENSON, M. S., T. D. O'BRIEN (2006): Feline models of type 2 diabetes mellitus. ILAR J. 47, 234-242.

DOI: 10.1093/ilar.47.3.234

HOENIG, M., H. YOSHIDO, H. KUROSAWA, Y. SHIMURA, H. YANAI, N. TADA (2010): Analysis of cholosterol levels in lipoprotein(a) with anion-exchange chromatography. J. Lipid Res. 51, 1237-1243.

DOI: 10.1194/jlr.D003624

HOENIG, M. (2012): The cat as a model for human obesity and diabetes. J. Diabetes Sci. Technol. 6, 525-533. DOI: $10.1177 / 193229681200600306$

HOENIG, M. (2014): Comparative aspects of human, canine and feline obesity and factors predicting progression to diabetes. J. Vet. Sci. 1, 121-135.

DOI: $10.3390 /$ vetsci1020121

HOENIG, M., C. WILKINS, J. C. HOLSON, D. C. FERGUSON (2003): Effects of obesity on lipid profiles in neutered male and female cats. American J. Vet. Res. 64, 299-303.

DOI: $10.2460 / a j v r .2003 .64 .299$
JERICO, M. M., DE CHIQUITO, K. KAJIHARA, M. ANTONIO, B. MOREIRA, R. GONZALES, F. L. A. MACHADO, V. S. NUNES, S. CATANOZY, E. R. NAKANDAKARE (2009): Chromatographic analysis of lipid fractions in healthy dogs and dogs with obesity or hyperadrenocorticism. J. Vet. Diagn. Invest. 21, 203-207.

DOI: $10.1177 / 104063870902100204$

JEUSETTE, I. C., E. T. LHOEST, L. P. ISTASSE, M. O. DIEZ (2005): Influence of obesity on plasma lipid and lipoprotein concentrations in dogs. American J. Vet. Res. 66, 81-86.

DOI: 10.2460/ajvr.2005.66.81

JORDAN, E., S. KLEY, N. A. LE, M. WALDRON, M. HOENIG (2008): Dyslipidemia in obese cats. J. Domest. Anim. Endocrinol. 35, 290-299.

DOI: 10.1016/j.domaniend.2008.05.008

KAWASUMI, K., T. MURAI, T. MIZOROGI, Y. OKADA, I. YAMAMOTO, K. SURUGA, K. KADOKURA, T. ARAI (2018): Changes in plasma metabolites concentrations in obese dogs supplemented with anti-oxidant compound. Front. Nutr. 5 (74).

DOI: $10.3389 /$ fnut.2018.00074

LARSEN, J. A. (2017): Risk of obesity in the neutered cat. J. Feline Med. Surg. 19, 779-783.

DOI: $10.1177 / 1098612 X 16660605$

LOFTUS, J., J. J. WARKSHLAG (2015): Canine and feline obesity: a review of pathophysiology, epidemiology and clinical management. J. Vet. Med.: Research and Reports 6, 49-60.

DOI: $10.2147 /$ VMRR.S40868

MARINO, L. C., B. D. X LASCELLES, S. L. VADEN, M. E. GRUEN, S. L. MARKS (2014): The prevalence and classification of chronic kidney disease in cats randomly selected within four age groups and in cats recruited for degenerative joint disease studies. J. Feline Med. Surg. 16, 465-472.

DOI: $10.1177 / 1098612 \mathrm{X} 13511446$

MORI, N., P. M. LEE, T. KIDO, T. SAITO, T. ARAI (2011): Potential use of cholesterol lipoprotein profile to confirm obesity status in dogs. J. Vet. Res. Commun. 35, 223-225.

DOI: $10.1007 /$ S11259-011-9466-X

MORI, N., Y. OKADA, N. TSUCHIDA, Y. HATANO, M. HABARA, S. ISHIKAWA, I. YAMAMOTO, T. ARAI (2015): Preliminary analysis of modified low-density lipoproteins in the serum of healthy and obese dogs and cats. Front. Vet. Sci. 17.

DOI:10.3389/fvets.2015.00034

O'CONNELL, E. M., M. WILLIAMS, S. L. HOLDEN, V. BIOURGE, A. J. GERMAN (2018): Factors associated with overweight cats successfully completing a diet-based weight loss programme an observational study. BMC Vet. Res. 14, 397.

DOI: $10.1186 / \mathrm{s} 12917-018-1740-5$ 
OKADA, Y., M. KOBAYASHI, M. SAWAMURA, T. ARAI (2017): Comparison of visceral fat accumulation and metabolome markers among cats of varying BCS and novel classification of feline obesity and metabolic syndrome. Front. Vet. Sci. 4 (17).

DOI: $10.3389 /$ fvets. 2017.00017

PAZAK, H. E, J. W. BARTGES, L. C. CORNELIUS, M. A. SCOTT, K. GROSS, T. L. HUBER (1998): Characterization of serum lipoprotein profiles of healthy, adult cats and idiopathic feline lipidosis patients. J. Nutr. 128, 2747-2750. DOI: $10.1093 / \mathrm{jn} / 128.12 .2747 \mathrm{~S}$

PHILIPS, A. M., J. B. COE, M. J. ROCK, C. L. ADAMS (2017): Obesity in veterinary medicine: insights from a thematic analysis of communication in practice. Front. Vet. Sci. 4, 117.

DOI: $10.3389 /$ fvets. 2017.00117

PRASENJIT, M., K. J. SUSHIL (2015): Obesity, oxidative stress, adipose tissue dysfunction, and the associated health risks: causes and therapeutic strategies. Metab. Syndr. Relat. Disord. 13, 423-444.

DOI: $10.1089 /$ met.2015.0095

SHOVELLER, A. K., M. R. C. DE GODOY, J. LARSEN, E. FLICKINGER (2016): Emerging advancement in canine and feline metabolism and nutrition. The Sci. World J. Article ID 902378, 1-2.

DOI: $10.1155 / 2016 / 9023781$

TAKAHARA, E., Y. MANTANI, K. G. UDAYANGA, W. M. QI, T. TANIDA, T. TAKEUCHI, T. YOKOYAMA, N. NOSHI, H. KITAGAWA (2013): Ultrastructural demonstration of the absorption and transporation of minute chylomicrons by subepithelial blood capillaries in Rat Jejunal Villi. J. Vet. Med. Sci. 75, 1563-1569.

DOI: 10.1292/jvms.13-0310

TARKOSOVA, D., M. M. STORY, J. S. RAND, M. SVOBODA (2016): Feline obesity - prevalence, risk factors, pathogenesis, associated conditions and assessment: a review. Vet. Med. 61, 295-307.

DOI: 10.17221/145/2015-VETMED

USUI, S., H. YASUDA, Y. KOKETSU (2015): Lipoprotein cholesterol and triglyceride concentration associated with dog body condition score; effect of recommended fasting duration on sample concentrations in Japanese private clinics. J. Vet. Med. Sci. 77, 1063-1069.

DOI: 10.1292/jvms.15-0032

VERBRUGGHE, A., M. BAKOVIC (2013): Peculiarities of one-carbone metabolism in the strict carnivorous cat and role in feline hepatic lipidosis. Nutrients 5, 2811-2835.

DOI:10.3390/nu5072811

VERBRUGGHE, A., M. HESTA (2017): Cats and carbohydrates: the carnivore fantasy. J. Vet. Sci. 4, 55.

DOI: $10.3390 /$ vetsci4040055

WATSON, D. G. (1996): Lipoprotein metabolism in dogs and cats. Comp. Hematol. Int. 6, 17-23.

DOI: 10.1007/BF00368097

ZORAN, D. L. (2010): Obesity in dogs and cats: a metabolic and endocrine disorder. Vet. Clin. North Am Small Anim. Pract. 40, 221-239.

DOI: $10.1016 /$ j.cvsm.2009.10.009

Received: 5 May 2020

Accepted: 10 September 2020

\section{CHALA, I. V., D. V. FESHCHENKO, O. A. DUBOVA, T. I. BAKHUR, O. A. ZGHOZINSKA, V. S. RUSAK: Promjene lipidnog profila krvi steriliziranih pretilih mačaka s dijabetesom. Vet. arhiv 91, 635-645, 2021. \\ SAŽETAK}

Cilj ovog rada bio je istražiti lipidni profil, lipidne frakcije i lipidnu peroksidaciju u krvi ster-iliziranih pretilih mačaka s dijabetesom. Za istraživanje formirane su tri skupine steriliziranih mačaka (mužjaka i ženki). Uspoređene su pretile mačke ( 7 - 9 bodova na BCS ljestvici od 9 bodova) s onima u kojih je pretilost komplicirana dijabetesom te klinički zdravim životinjama s normalnim tjelesnim pokazateljima (4 - 5 BCS bodova). Analiziran je lipidogram, frakcije lipopro-teina visoke gustoće (HDL), lipoproteina niske gustoće (LDL) i lipoproteina vrlo niske gustoće (VLDL), kilomikroni (CM), produkti lipidne peroksidacije (POL) - lipidna hidroperoksidaza (GPL) i malondialdehid (MDA). U pretilih je mačaka uočen snižen HDL i fosfolipidi te povišen LDL, VLDL, CM, trigliceridi i kolesterol. Nije bilo znakovite razlike u metabolizmu lipida i lipo-proteina između kastriranih ženki i mužjaka. Uočena je sklonost porastu koncentracije lipopro-teina, triglicerida i kolesterola u mužjaka kao i porast fosfolipida u ženki. U pretilih mačaka s dija-betesom omjer fosfolipida i kolesterola bio je manji od jedan, dok je u zdravih mačaka bio veći od jedan. Pretilost i dijabetes potiču lipidnu peroksidaciju i povećavaju koncentraciju GPL-a i MDA-a, koja je najveća u krvi ženki s tom patologijom.

Ključne riječi: mačka; pretilost; trigliceridi; kolesterol; fosfolipidi; lipidni hidroperoksidi 
